\title{
Noughts AND CROSSES: THE SilenCE OF THE CHURCHES IN THE Holocaust YeARS
}

\section{COLIN TATZ}

This essay is about the indifference, even the hostile indifference, of Christian churches to the Jewish experience in the 1930s and 1940s. Even a brief review of the attitudes and actions of the German Catholic and Protestant churches, of two Popes, of the highly-regarded theologian Dietrich Bonhoeffer and of the German Jews' responses leads to this conclusion: that there are much simpler explanations of their silences and their moral abdications than can be found in the grand theorising so often required by the humanities and social sciences.

Two factors make this is a difficult assignment. First, identifying let alone pinpointing emotions and attitudes, which is so much harder than assembling chronology and narrative. Second, finding the appropriate words to capture and comprehend church conduct during the Holocaust era. (And then beyond the Shoah to church silence during Burundi, Rwanda, Somalia, Guatemala, North Korea, Bangladesh, Kosovo, Bosnia, Iraq, Darfur, among other such events.)

One tries to find and understand the mechanisms, the transmission belts that 'drove' their behaviour. Greed, revenge, hate and contempt explain many acts of evil; Samaritanism, generosity, charitableness, even altruism underlie acts of goodness. A word that doesn't seem to belong in the vocabularies of good and evil is want. It seems innocuous enough. But want can mislead. To want something is to wish or hope for it, to yearn or pine or even crave for it; the verb implies action towards something positive and definable. Not to want is a much more passive notion, even a negative one. Wanting has the common meaning of lacking, being inadequate, disappointing, sometimes not needing, and 
often, being unacceptable. These are not merely normal emotions and behaviours or psychological states of being; they are also political terms and attitudes and it is in these latter senses that I look briefly at what Christians and Jews wanted, didn't want, and the nature of their wanting in relation to Jews in the Europe of the 1930s and 1940s.

Indifference is another relevant word, one that on the face of it indicates neither want nor not want. Written or spoken, it conveys a sense of neutrality, of not caring one way or the other, a shrug signifying lack of concern, lack of interest, coolness or even coldness, or simply disdain, disregard or dismissiveness. It doesn't connote strength of feeling, certainly not passion. In his lectures, Yehuda Bauer, the doyen of Holocaust historians, always talks about hostile indifference towards Jews in that era-a notion that embodies intense feelings of either antagonism, bitterness, unkindness, malice, callousness or spite, or all of those feelings. Joining 'hostile' to 'indifference' may well be a contradiction but that in itself is appropriate for a period of history replete with contradiction, including the inconsistency of the celebrated German Protestant theologian Bonhoeffer.

Two more terms need consideration: worthy and its opposite, unworthy. Genocide scholars sometimes, but not often, talk about worthy and unworthy victims, those who do and those who don't warrant rescue or any of the several forms of intervention. Worthy here means deserving of, meriting, justifying, warranting attention or action. The Catholic and Protestant teaching that Judaism was superseded by Christianity and was therefore obsolete is but one form of unworthiness. Centuries of Christian teaching of contempt for Jews is another. ${ }^{1}$ In World War II, several Polish underground movements wouldn't give arms to Jewish

${ }^{1}$ Isaac, Jules (1964), The Teaching of Contempt: Christian roots of antiSemitism, New York, Holt, Rinehart and Winston. 
partisans and some local right-wing resistance movements hunted down Jews in order to kill them. That was another litmus of unworthiness. ${ }^{2}$ In 1985, when he was Mayor of Darmstadt, Günther Metzger told the German Council of Sinti and Roma people that their request to be included in remembrance ceremonies to mark the liberation of the Bergen-Belsen camp 'insulted the honour' of the Holocaust by wishing to be associated with it. ${ }^{3}$ That is as good an exemplar of unworthiness as we will find. [Woodcock's essay here shows just how unworthy are the Romani in Romanian society.]

\section{The Catholic Church and the Jews}

The Catholic church isn't a monolithic structure now and it wasn't so in the Holocaust years. There were hundreds of Catholic churches and thousands of church men and women: some saved Jews, others defended Jews, some betrayed Jews and some killed Jews. Father Jozef Tiso, a priest, headed a Nazi puppet state in Slovakia from where Jews were deported to Auschwitz: 'It is a Christian action to expel the Jews, because it is for the good of the people, which is thus getting rid of the pests.' ${ }^{4}$ [See Paul O'Shea's essay in this volume.] Yet Dominican nuns, led by Sister Bertranda (Anna Borkowska), assisted and even ran guns for the famous partisan Abba

${ }^{2}$ Krakowski, Shmuel (1984), The War of the Doomed: Jewish armed resistance in Poland, 1942-1944, Teaneck, New Jersey, Holmes and Meier.

${ }^{3}$ Wiesenthal, Simon, newsletter, quoted by Hancock, Ian (1988) in his 'Uniqueness of the Victims: Gypsies, Jews and the Holocaust', Without Prejudice: The EAFORD International Review of Racial Discrimination, 2, 45-67.

4 Rothkirchen, Livia (1967), 'Vatican Policy and the "Jewish Problem" in "Independent" Slovakia (1939-1945)', in Eck, Nathan and Kubovy, Aryah Leon (eds), Yad Vashem Studies, vol 6, Jerusalem, Yad Vashem, 50 . 
Kovner and his men in the Vilna (Vilnius) ghetto underground. 5

The noticeably short Vatican document, We Remember: A reflection on the Holocaust (The Shoah) - released on 16 March 1998, more than 50 years after the events - was presented by Edward Idris Cardinal Cassidy to a large Sydney audience a year later. ${ }^{6}$ Cassidy talked of 'the sons and daughters of the Church...who fostered longstanding sentiments of mistrust and hostility that the Vatican documents refer to as antiJudaism'. ${ }^{7}$ If only it had been merely mistrust and hostility. That Jews could have lived with, as they have done for two millennia - and longer. But they had to live with and die from things infinitely greater than mere mistrust and hostility. They, and the Catholic church, have also had to live with the reality, expressed by Christian philosopher Marcel Dubois, that the centuries-old Christian anti-Judaism prepared the soil for modern antisemitism and the Holocaust' ${ }^{\prime}{ }^{8}$

Why did people behave the way they did? The Cardinal

${ }^{5}$ Paldiel, Mordecai (2006), Churches and the Holocaust: Unholy teaching, good Samaritans and reconciliation, Jersey City, Ktav, 219-21.

6 Organised by the St Thomas More Society and the New South Wales Society of Jewish Jurists and Lawyers, Wesley Institute, Sydney, 29 July 1999. The booklet - We Remember: A reflection on the Holocaust [The Shoah], containing the speeches of Edward Idriss Cardinal Cassidy, the Australian Governor-General Sir William Deane, Rabbi Raymond Apple and Professor Colin Tatz, was published by the sponsors. The full text of Tatz's presentation is also found in his (2003), With Intent to Destroy: Reflecting on genocide, London, Verso, 58-66. Some of the material in these two sections on Catholics and Popes comes from that source.

7 We Remember, 9.

8 Bacharach, Walter (2000), 'The Catholic anti-Jewish prejudice, Hitler and the Jews', in Bankier, David (ed), Probing the Depth of German Antisemitism: German society and the persecution of Jews, 1933-1941, New York, Berghahn Books, 418. 
conceded that 'many Christians did in fact fail to give every possible assistance to those being persecuted'; he talked of people who 'failed to give the witness that might have been expected of them as Christ's followers'. The tenor of this is that, at worst, the Catholic church was merely one third of the Holocaust triangle ${ }^{9}$ that comprises the perpetrators and victims as well as the bystanders, those who by their indifference-or even their hostile indifference-allowed it to happen. Many churches and churchmen were more than bystanders: they were accessories, accomplices, collaborators, certainly companions to both ideas and actions-and murderers. The Vatican document has several references to the church or its adherents as co-equal victims. But there is a blasphemy in equating the fate of the Jews of Europe with the fate of the Catholic church or even several hundred of its servants. (There are also curious omissions of the dead in We Remember: the forgetting of, among others, 220,000 Roma, as many as 5.7 million Russians prisoners of war, at least 3.5 million non-Jewish Poles, nearly 6 million Ukrainian civilians, 8.2 million Russian civilians, and tens of thousands of antifascists, Serbian patriots, Jehovah's Witnesses and gay men.)

There are, literally, innumerable examples of Catholic clergy, whether in Germany or among her satellite allies, who strongly supported Nazism and were, in many ways, perpetrators. Among others, Ernst Helmreich has written a major work on The German Churches Under Hitler; ${ }^{10}$ Klaus Scholder has published a two-volume analysis of The Churches

${ }^{9}$ Most Holocaust historians use this diagramatic triangular metaphor. In my courses I use a five-sided figure which adds the beneficiaries and the denialists.

${ }^{10}$ Helmreich, Ernst (1979), The German Churches Under Hitler: Background, struggle and epilogue, Detroit, Wayne State University Press. 
and the Third Reich ${ }^{11}$ and Kevin Spicer has provided much detail in several works, especially in his more recent portrait of Hitler's Priests. ${ }^{12}$ This latter book devotes some 60 pages to biographies of 138 leading 'brown priests'.

Some aspects of church involvement need brief discussion. The essential thrust of We Remember is that there was a 'them' and 'us' dichotomy: 'us' or 'we' were the anti-Jewish church leaders and ideology-makers who taught and preached a doctrine of contempt, now regarded as morally and ethically wrong; 'them' were an aberrant group of pagan Nazis whose roots lay outside of Catholic Christianity and who murdered in the name of blood and race. This kind of rationalisation does not become the Vatican. It echoes the German historian, Ernst Nolte, who talked about 'us' or 'we' Germans, the good people, the anti-Nazis, and the 'them' Germans, Nazis who seemingly descended from some alien spaceship in 1933 and who were vanquished by the forces of good in $1945 .{ }^{13}$

Some 43 per cent of Germans were Catholics, and a significant 22.7 per cent of the Schutzstaffeln (SS) were adherents, attendees at mass, seekers of rites and rituals. Hitler was undoubtedly a radical figure, the one who put the extermination engine into operation. But the engine, and most of the vehicle's parts, was assembled well before he came to power. His radicalism was in removing the brakes that had

11 Scholder, Klaus, The Churches and the Third Reich (1987), vol 1: Preliminary History and the Time of Illusions 1918-1934, London, SCM Press Ltd; Scholder (1988), vol 2: The Year of Disillusionment 1934: Barmen and Rome, London, SCM Press Ltd.

12 Spicer, Kevin (2008), Hitler's Priests: Catholic clergy and National Socialism, DeKalb, Northern Illinois University Press.

${ }^{13}$ Nolte, Ernst, 'A past that will not pass: a speech that could be written but not delivered', Frankfurt Allgemeine Zeitung, 6 June 1986, reproduced in several places, including Yad Vashem Studies XIX (1988), Jerusalem, Yad Vashem, 65-73. 
always held back the Church, namely, the injunction of St Augustine in the fourth century that Jews could be and even should be demeaned, brought low, expelled, harassed, deported, reviled - but not killed. ${ }^{14}$

In the Weimar period in the 1920s, bishops spoke out against the glorification of race and blood, but said nothing about anti-Jewish propaganda. They did, however, talk strongly about the destructive influence of the Jews. The main proponents were men like Fathers Josef Roth, Lorenz Pieper, Magnus Gött, the Franciscan Erhard Schlund, the Jesuit Gustav Gundlach and Bishop Michael Buchberger of Regensburg.

In the post-Weimar period, Hitler had strong dialogue with the Catholic leadership, who in turn began an appreciation of the values of racial purity. Archbishop Conrad Gröber ('Conrad the Brown'), while heavily involved in winning over the German bishops to the Vatican's signing a concordat with the Reich, stated:

Every people bears itself the responsibility for its successful existence, and the intake of entirely foreign blood will always represent a risk for a nationality that has proven its historical worth. Hence, no people may be denied the right to maintain undisturbed their previous racial stock and to enact safeguards for this purpose. The Christian religion merely demands that the means used do not offend against the moral law and natural justice. ${ }^{15}$

Later, he protested against the euthanasia program but not against the treatment of Jews.

14 Saint Augustine (1972), The City of God Against the Pagans, book 18, chapter 46, translation by Henry Bettenson, Harmondsworth, Penguin Books edition.

${ }^{15}$ Scholder, Klaus, vol 1, 394-95. 
The famous Advent sermons of 1933 by Cardinal Michael von Faulhaber have been misinterpreted: he said that he didn't object to the attempt to keep national characteristics 'pure and unadulterated' but he objected to placing loyalty to race above loyalty to the church. This was misinterpreted as Catholic condemnation of Nazi ideology. It wasn't. He was a willing defender of the Old Testament, but while the people of Israel before Christ were the vehicles of divine revelation, those who came after were but 'restless wanderers over the earth'. He was therefore 'not concerned with defending the Jews of our time' - because, he insisted, 'the Jews can help themselves'. ${ }^{16}$ [This was said in the context of the 'failed' Nazi attempt at a Jewish economic boycott, promoted by Julius Streicher, on 1 April 1933. Beginning a few weeks earlier, in March 1933, Jews and non-Jews had met in rallies at New York's Madison Square Garden to protest at German treatment of Jews. These meetings caused Nazis to fear an American boycott of their goods, leading to this notion that Jews were not only all-powerful but also capable of looking after themselves.] Cardinal-Archbishop Adolf Bertram used a similar turn of phrase when he and Faulhaber pointed out to the Pope that there were 'immediate issues of greater importance in the long term: schools, the maintaining of Catholic associations, sterilization'. ${ }^{17}$ Although he condemned the euthanasia program, Faulhaber never once uttered a word about the persecution and extermination of the Jews. Hitler, he was happy to say, was 'the first statesman, aside from the Holy Father, who raised his voice against bolshevism'. ${ }^{18} \mathrm{He}$

${ }^{16}$ Helmreich, 276.

17 Cornwell, John (1999), Hitler's Pope: The secret history of Pius XII, London, Viking, 140; see also Bacharach, Walter (2000), 'The Catholic anti-Jewish prejudice, Hitler and the Jews', in Bankier, David (ed), Probing the Depth of German Antisemitism: German society and the persecution of Jews, 1933-1941, New York, Berghahn Books, 417.

18 Helmreich, 239. 
admired the Führer as 'a man of peace'.

The Catholic church agreed to the Nuremberg Laws which prohibited marriages between Jews and Aryans: in short, the church agreed to an inadmissible infringement of her spiritual jurisdiction to give sacraments to a baptised Jew. While many Catholic leaders abroad condemned these Laws, Bishop Alois Hudal, head of the German church in Rome, said the Nuremberg Laws were 'essential as a measure of self-defence against the influx of foreign elements'. This 'Semitic race', he wrote, wanted to 'become the financial masters of the Eternal City'. ${ }^{19}$ Much later, he was to assist in the escape of a dozen major war criminals, including Adolf Eichmann, three Nazi camp commandants, Franz Stangl, Gustav Wagner and Alois Brunner, and such men as Klaus Barbie, (Croatian) Ante Pavelic and Josef Mengele. ${ }^{20}$

A pastoral letter from the German bishops, by Faulhaber, was read on the first Sunday in January 1937. It agreed with Hitler's perception of the Bolshevik danger:

The German Bishops consider it their duty to support the head of the German Reich by all those means which the Church has at its disposal. Co-operation in repelling this threat is a religious task. ${ }^{21}$

In effect, the bishops were at one with Hitler in perceiving Jews as the chief engineers, carriers and exploiters of Bolshevism. Gröber characterised Bolshevism as 'an Asiatic state despotism, in point of fact in the service of a group of

${ }^{19}$ Godwin, Peter (2004), Hitler and the Vatican: Inside the secret archives that reveal the new story of the Nazis and the Church, New York, Free Press, 43-46.

20 Cornwell, 267.

${ }^{21}$ Lewy, Guenter (2000), The Catholic Church and Nazi Germany, New York, De Capo Press, 219-10. 
terrorists led by Jews' ${ }^{22}$

The Bishop of Limburg, Antonius Hilfrich, was an opponent of the euthanasia program. He admitted the Jewishness of Jesus 'but the Christian religion has not grown out of the nature of this people'; rather, 'it has had to make its way against this people', those guilty of the murder of God. ${ }^{23}$ Given these sentiments from senior clergymen, Lewy says it was no wonder that the lower-ranking churchmen felt free to express not just their contempt but their hatred of Jewry.

'Kristallnacht', the Goebbels-orchestrated pogrom of 9 November 1938, was in so many ways the trailer for the 'Final Solution'. The late rabbi and philosopher Emil Fackenheim always said that following the destruction of the Temple in 70 $\mathrm{CE}$, this was the second-most climactic event in Jewish history to that point-because that action singled out Jews simply and merely because they were. Apart from Provost Bernhard Lichtenberg of St Hedwig's Cathedral in Berlin, this event was not commented upon by German Catholic churchmen (in sharp contrast to the condemnation by cardinals in France, Portugal and Belgium). Lichtenberg-the blessed and beatified Catholic, the man who had been imprisoned by the Gestapo for, among several things, asking his congregants at the end of his services to pray for the Jews - lamented: 'What took place yesterday, we know; what will be tomorrow, we do not know; but what happens today, that we have witnessed; outside this church the synagogue is burning, and that is also a house of God'. ${ }^{24} \mathrm{He}$ was taken to Dachau, and died en route, of causes unknown.

The church in parts of Germany rejected from service and

${ }^{22}$ Lewy, Guenter (1964), 'Pius XII, the Jews and the German Catholic Church', Commentary, 37, 2, 25.

${ }^{23}$ Lewy, 'Pius XII, the Jews ...', 24-25.

${ }^{24}$ Lewy, The Catholic Church, 84. 
sacraments those ordered to wear yellow armbands. They were fellow Catholics but they were Jews. The church in Germany certainly protested against the euthanasia program and the Bishop of Münster, Clemens Galen, has rightly been honoured as an heroic figure for his opposition. But, like Gröber and von Faulhaber, he never protested against Jewish treatment. ${ }^{25}$ That was left to the lone Lichtenberg.

By the end of 1942, the German episcopate was well informed of what was happening. Colonel Kurt Gerstein had joined the SS to 'take a look into Hitler's kitchen', to see for himself what was happening to Jews: after witnessing a gassing at Belzec death camp, he tried to inform the Papal Nuncio, Cesare Orsenigo. The Monsignor refused to see him. Monsignor Wilhelm Berning, Bishop of Osnabrück, and a strong Nazi sympathiser, wrote in his notes of 5 February 1942 that 'the plan for a total elimination of the Jews clearly exists' ${ }^{26}$ Monsignor Conrad Gröber, Archbishop of Freiberg, told the Pope on 14 June 1942 about the Einsatzgruppen massacres in Russia: 'The Nazi conception of the world is characterised by the most radical anti-Semitism, going as far as the annihilation [Vernichtung] of Jewry, not only in its spirit but also in its members.' 27

The German bishops made no statements about the fate of Jews in Dachau or in other camps, but expressed concern solely at the possible intrusion into the indissolubility of Christian marriages. Archbishop-Cardinal Adolf Bertram,

${ }^{25}$ Griech-Polelle, Beth (2001), 'Image of the churchman-resister: Bishop von Galen, the euthanasia project and the sermons of the summer of 1941', Journal of Contemporary History, 36, 1, 41-57.

26 Phayer, Michael (2000), The Catholic Church and the Holocaust, 19301945, Bloomington, Indiana, Indiana University Press, 68.

27 Wistrich, Robert (2001), Hitler and the Holocaust, London, Weidenfeld \& Nicolson, 136. 
President of the German Bishops' Conference and the preeminent Catholic cleric, and others expressed concern about Jewish converts in the camps but not about Jews in general. (Three days before the war ended, the same Bertram said a Mass in fond memory of Hitler a week after his suicide.) In all their pleas and pleadings about the right to life and liberty, none of these men, including the 'heroic' figures of von Faulhaber and von Galen, could actually utter the word 'Jew'. Opposed to the euthanasia program to the extent that it least stopped, officially - though it continued secretly until beyond the last day of the war-they couldn't find it within their Christianness to oppose the Jewish programs. Unlike the Belgian, French and Dutch bishops, the German bishops never spoke out when Jews were being transported from their country. ${ }^{28}$ These were the men who ordered denial of the sacraments to Catholics who engaged in duelling or who sought cremation rather than burial-but didn't deny such rites to men who killed Jews.

\section{Two Popes and the Jews}

On 14 March 1937, Achille Ratti, Pope Pius XI, wrote the first ever encyclical in German, 12 pages addressed to the German bishops. A week later it was read from every pulpit. He declared that 'whoever exalts race or nation or the State to the highest norm and worships them like idols perverts and distorts the divine order of things... True Christianity proves itself in the love of God and in the active love of one's neighbour.' He added that 'human laws which run counter to natural laws are not obligatory in conscience'..$^{29}$ The encyclical was entitled Mit brennender Sorge, with serious or burning concern.

In 1938 he asked the renowned American Jesuit writer on Black-White relations, John LaFarge, to help him pen another

${ }^{28}$ Helmreich, 363.

${ }^{29}$ Cornwell, 181-83. 
encyclical, Humani Generis Unitas, a document which some historians, including Conor Cruise O'Brien, have suggested (wrongly perhaps, but quite seriously) may have averted the Holocaust. LaFarge was assisted by Gustav Gundlach, who earlier had written an encyclopaedia article defending a 'permissible anti-Semitism'. Ethnic and racist antisemitism was 'unchristian', he wrote, but he condoned 'antiJewishness' as a moral and legal means of com-bating 'dangerous influences of Jewish ethnicity in the ambit of economics, politics, press, theatre, cinema, science and the arts'. ${ }^{30}$ Unlike Mit brennender Sorge, it mentioned Jews and antisemitism. At paragraph 132, he wrote: 'Even those who in time of war fought bravely for their country are treated as traitors, and the children of those who laid down their lives in their country's behalf are branded as outlaws by the very fact of their of their parentage... This flagrant denial of human rights sends many thousands of helpless persons out over the face of the earth without any resources. Wandering from frontier to frontier, they are a burden to humanity and to themselves'. ${ }^{31}$

Even so, there was no denunciation of Nazi policies and no condemnation of anti-Jewish programs. The draft, regrettably, was still very much in traditional Catholic mould. It repeated the theological casuistry about the historic curse on Jews for their rejection of Christ, and the right to continue with conversion goals. As to the circumstances in which Jews find themselves in various countries, this gives rise 'to very different problems in the practical order' and so the church 'leaves to the powers concerned the solution to these

30 Cornwell, 189.

31 Passelecq, Georges and Suchecky, Bernard (1997), The Hidden Encyclical of Pius XI, New York, Harcourt Brace and Company, 24647. 
problems' in the 'truly profane spheres'. ${ }^{32}$ The 100-page draft didn't go any further or anywhere and it was left to 1965, to the most significant Nostra Aetate of the Second Vatican Council, to declare a total break with the centuries of contempt. ${ }^{33}$

When Pius XI died in February 1939, Bernard Joseph, on behalf of the executive of the Jewish Agency, wrote to the Patriarch in Jerusalem: ${ }^{34}$

In common with the whole civilised community, the Jewish people mourns the loss of one of the greatest exponents of the cause of international peace and goodwill... More than once did we have occasion to be deeply grateful for the attitude which he took up against the persecution of racial minorities and in particular for the deep concern which he expressed for the fate of the persecuted Jews of Central Europe. His noble efforts on their behalf will ensure for him for all time a warm place in the memories of Jewish people wherever they live.

These are not the words that Jews will ever come to use of his successor, Eugenio Pacelli, Pope Pius XII. Not only Jews but many Catholic thinkers despaired then, and now, of this man's failure to do certain things that were within his powers to do. He failed to promulgate an explicit and direct condemnation of the war of aggression, to speak out openly against the acts of violence against Jews and others under Nazi occupation. He had full knowledge of the facts from early on, and his sin, if I may use the term, was not to use the influence he had within him. He continued to remain silent

32 Passelecq and Suchesky, 256-57.

33 There are several key works on Vatican Council II: see Cassidy, Edward Idriss Cardinal (2005), Ecumenism and Inter-Religious Dialogue: Unitatis Redintegratio, Nostra Aetate, New Jersey, Paulist Press.

${ }^{34}$ Lapide, Pinchas (1967), Three Popes and the Jews, New York, Hawthorn Books, 116. 
despite ceaseless appeals from his own adherents, from Jews and from governments, to speak out. On 6 March 1943, Bishop Konrad von Preysing asked the Pope to help save Jews, 'the many unfortunate innocents', still in Berlin and awaiting deportation. In April 1943, he wrote to Preysing saying he wouldn't speak out, advising caution 'to avoid the greater evil (ad maiora mala vitanda)'. ${ }^{35}$ What could possibly have been a greater evil? He condoned the Vichy Government's 'Jewish Statutes'. The French bishops protested, but Léon Bérard, the Vichy Ambassador to the Holy See, reported to Marshal Petain that the Vatican did not consider such laws to be in conflict with Catholic teaching. ${ }^{36}$

The razzia against the Jews of Rome began early on Saturday morning, 16 October 1943: Jews were being deported from literally under the Vatican balcony. In his capacity as Bishop of Rome, Pius XII may have ordered nuns and priests to give them shelter and sanctuary, but Paul $\mathrm{O}^{\prime}$ Shea and others ${ }^{37}$ have established that there is no evidence, anywhere, of such a written or spoken order. (That he didn't stop such rescue efforts can hardly be used as evidence of his goodness, as a few faithful have asserted.) It was not uncommon for Catholics to use the Pope or his name as a moral justification for action and what is clear is that despite lack of public leadership from the Vatican, Italians (as Italians, not necessarily as Christians) rescued 7,000 Jews and hid

35 Wistrich, 149-51.

36 Phayer, 2000, 5.

37 O'Shea, Paul (2008), A Cross Too Heavy: Eugenio Pacelli: Politics and the Jews of Europe 1917-1943, Sydney, Rosenberg Publishing, reprinted by Macmillan 2011; Phayer, Michael (2007), Pius XII, the Holocaust and the Cold War, Bloomington, Indiana University Press; Zucotti, Susan (2000), Under his Very Windows: the Vatican and the Holocaust in history, New Haven CT, Yale University Press. 
them. One thousand Rome Jews went to Auschwitz and only 15 returned. In O'Shea's view, of all Pacelli's actions or inactions, his absent voice on the Jews of Rome was his most abject miscalculation, his worst misjudgement. Pius, according to Yehuda Bauer, raises a moral question: who is a saintly person? His answer: 'Pius rejected possible martyrdom at German hands for defending Jews. Probst Lichtenberg in Berlin died for that reason. Who should be proclaimed a saint-Lichtenberg or Pacelli?' 38

There is a point to all of this: everyone should welcome the church's admissions, regrets, the church's remembering and the church's call for Teshuvah, repentance in charity of word and deed, something Cardinal Cassidy rightly described as going well beyond apology. But there is something else that is needed following the Cardinal's promise that this document is not the last Vatican word on the subject: that remembering has to be full memory, not partial memory, not selective memory, not just of the Jews but those millions of non-Jews persecuted and murdered by the Nazis, those whom Michael Berenbaum has called a 'mosaic of victims'. ${ }^{39}$ There was, and is, the good, the bad, the ugly, and the wanting. We all need to look at all of these behaviours, face them, and come to terms with what they are.

\section{The Protestants and the Jews}

Looking at or into that landscape of death one understands the search for light and for some optimism. In 1953, Israel passed the Martyrs' and Heroes' Remembrance (Yad Vashem) Law, which enabled the official recognition of Righteous Gentiles, or the 'Righteous Among the Nations' - those who risked their lives, positions or property to save Jews, for no

${ }^{38}$ Bauer, Yehuda (2008), 'His silence spoke volumes', The Tablet, London, 4 October, 8-9.

39 Berenbaum, Michael (1990), Mosaic of Victims: Non-Jews persecuted and murdered by the Nazis, New York, New York University Press. 
reward. To have found and honoured just on 24,333 such people to date [1 January 2012] is to have uncovered a small nugget of altruism amid a universe of unalloyed evil. When we highlight Martin Niemöller, Dietrich Bonhoeffer, Helmut Gollwitzer, Elisabeth Schmitz, Marga Meusel, Hans Ehrenberg, Karl Immer and Julius von Jan, it makes us feel better about humanity. It may even offer a sense of redemption for those who feel guilt. But this predilection to always look on the bright side of things is a strange, even perverse, form of political synecdoche: looking at a part of something to represent the whole, usually with the intent of equating the whole with the part. These men and women were certainly a part of resistance to National Socialism but nowhere near representative of Protestant Germany. Wolfgang Gerlach, whose doctoral dissertation in 1970 began both the exhumation and autopsy of German Protestant antisemitism, has a better perspective. The title of his book on the Confessing Church-the Protestant schismatic church that opposed the attempts to Nazify the church -and the persecution of the Jews is apt enough: And the Witnesses Were Silent. ${ }^{40}$

Scholder contends that the Protestant churches laid themselves 'open to völkisch antisemitism in the 1920s ...under its spell even the churches did not see and hear what was going on before their very eyes, on their doorsteps and within their walls'. ${ }^{41}$ His conclusion is fitting, except for the bizarre dates he attributes. That brand of popular antisemitism was alive and well centuries earlier. At times it was essentially racial antisemitism at work rather than simply traditional public sentiment, as shown in the letter written by

40 Gerlach, Wolfgang (2000), And the Witnesses Were Silent, University of Nebraska Press.

${ }^{41}$ Scholder, vol 1, 270. 
Lutheran Pastor Reichelmann to Der Stürmer in 1935: 'We stand enthusiastically behind your struggle against the Jewish death watch beetles which are undermining our nation...the murderers of Our Saviour'. ${ }^{42}$ Or we can note the sentiments of Otto Dibelius, the church's superintendent, who sermonised 'that one cannot ignore the fact that Judaism is taking a leading role in all of the destructive manifestations of modern civilisation'; 43 in the wake of violence and measures against Jews in 1933, he wrote, these actions 'will be for the best of the world'. ${ }^{4}$

In both Catholic and Protestant responses to this tremendum of the twentieth century there is a curious consistency: that Nazi antisemitism was quintessentially racial (and evil) and therefore quite separate from the traditional, völkisch, religious (and permissible) variety of that phenomenon. The late doyen of historians of antisemitism, Jacob Katz, encapsulated the essential relationship: 45

The key to the understanding of what happened in the nineteenth and twentieth centuries in Jewish-Gentile relations, including its catastrophic climax in the Holocaust is not to be found in the immediate past, but in the course of Jewish history, at least since its entanglement with the history of Christianity.

42 Conway, John (1968), The Nazi Persecution of the Churches, 1933-45, London, Weidenfeld \& Nicolson, 377.

${ }^{43}$ Gerlach ,Wolfgang (1996), in Wollenberg, Jorg (ed), The German Public and the Persecution of the Jews, 1933-1945: 'No one participated, no one knew', New Jersey, Humanities Press, 68-71.

${ }^{44}$ Büttner, Ursula (2000), '"The Jewish problem becomes a Christian problem": German Protestants and the Jews in the Third Reich', in Bankier, David (ed), Probing the Depth of German Antisemitism: German Society and the Persecution of Jews, 1933-1941, New York, Berghahn Books, 438.

45 Bacharach, 418. 
After Napoleon's defeat, and at least until 1876, all birth, death and marriage records were in the hands of the German churches, kept in parish registers. These details became crucial for the Nazi identification of Jews. The supply of such information by the churches was doubtless given as a civic duty and as an act of loyalty - but with the knowledge that there would be serious consequences (of some kind) for the individuals named. ${ }^{46}$

We know much of the narrative history of the German Christians and the Confessing Church. In 1933, Hitler was opposed to the pluralism of the Protestants and so he attempted a unification of the 28 Evangelical churches (including Lutheran, Reformed and United) under one Reich Bishop. This was to be a counterpart to the concordat signed by Hitler and the Vatican in 1933. The scheme had popular support, with Nazism finding favour among the Deutsche Christen movement. That church group wanted to include in religion what had already been put in place elsewhere-the Aryan Paragraph. Just as Jews were excluded from organisations, federations, political parties and public life, so they were to be excluded from Christian teaching. There was, above all, to be a complete disassociation from the Old Testament (unlike some of the Catholic hierarchy who sought to preserve that document).

The Paragraph meant that Jewish converts were outside the church, and it was this exclusion, not to the treatment of Jews in general, that motivated the Pastors' Evangelical League to active opposition to National Socialism, at least in religious affairs. It focused around Martin Niemöller and centred on Karl Barth's celebrated essay 'Theological Existentialism Today'. The Aryan Paragraph was seen as a

${ }^{46}$ Barnett, Victoria (1988), For the Soul of the People: Protestant protest against Hitler, New York, Oxford University Press, 37-38. 
violation of Christian teaching: evangelical churches wanted to spread the gospel, not be constrained from doing so.

The Confessing Church resisted in several ways, including hiding some 2,000 Jews. Pastor Heinrich Grüber established an office, a Büro, in Berlin to give advice and assistance not to Jews in general but to 'Christian Jews' during the brief period of forced expulsion under Eichmann's control - until he was arrested in December 1940. ${ }^{47}$ His efforts were rarely admired or applauded by most of the Protestant churches.

Hitler lost patience with these men and women and allowed ideologues like Alfred Rosenberg and Martin Bormann to harass them. They did. Between 1937 and 1945, 18 pastors were confined to camps; Helene Jacobs was jailed and the man she served and revered, the Jewish-born jurist, Franz Kaufmann, who ran a group that hid Jews, was shot. Niemöller was confined in Sachsenhausen and Dachau and Bonhoeffer was executed at Flossenbürg in April 1945.

In 1935, a deaconess of the Berlin church, Marga Meusel, objected to the Confessing Church's timidity. She wanted to know why the church was concerned only for itself and for its Jewish converts rather for those who were suffering most. In 1938, one Protestant voice (among the very few) was heard about 'Kristallnacht' - that of Julius von Jan, a Protestant minister in the town of Württemberg, who asked: 'who would have thought that one single crime in Paris [the Polish-Jewish youth Herschel Grynszpan shooting German diplomat Ernst vom Rath] would have resulted in so many crimes being committed in Germany?' 48

It wasn't merely a matter of timidity but rather of silence. There were no voices about the Nuremberg Laws of 1935 that

${ }^{47}$ Conway, 223.

${ }^{48}$ Hockenos, Matthew (2004), A Church Divided: German Protestants confront the Nazi past, Bloomington, Indiana University Press, 35. 
'uncitizened' the Jews of Germany. There was but von Jan's reflection on the night of 9 November 1938. There was nothing to be heard about the Judeocide as such. There was only a secret memorandum to Hitler in 1936 protesting at the campaign against the Jews, the camps and the pervasiveness of the Gestapo. ${ }^{49}$ On 19 October 1945, the Council of the Evangelical Church admitted to the moral failure of their Christianity. The Stuttgart Declaration (or Confession) of Guilt said, in part: 'For long years we have fought in the name of Jesus Christ against the spirit that found its terrible expression in the National Socialist rule of violence; yet we accuse ourselves for not speaking out more courageously, praying more faithfully, believing more gladly, and loving more ardently'. The word 'Jew' did not appear. The word 'more' suggests that the churches did do things but could have said and done 'more'. The significant Darmstadt declaration of 1947 called for the churches to reconsider and improve their attitudes towards and beliefs in the political structures that led to Germany's disaster, but many branches refused to sign it. ${ }^{50}$ In 1950, the synod of the Evangelical Church in Germany resolved, inter alia, that 'We ask all Christians to disassociate themselves from all anti-Semitism and earnestly resist it whenever it stirs again, and to encounter Jews and Jewish Christians in a brotherly spirit...'. ${ }^{51}$

\section{Bonhoeffer and the Jews}

This essay began as a presentation to the fourth annual Bonhoeffer Conference organised by Father Stephen Moore at

\footnotetext{
49 Wistrich, 133.

${ }^{50}$ Fahlbusch, Erwin et al, (ed) (1999), The Encyclopedia of Christianity, Grand Rapids MI, Eerdmans-Brill, 775.

${ }^{51}$ Hockenos (2004).
} 
Kincumber, north of Sydney, in November 2008.52 A Christian-Jewish group met to reflect on the discipleship and legacy of Bonhoeffer, using as its title the phrase coined by biographer Stephen Haynes to assess the Bonhoeffer legacy'A Cautious Embrace'. Historian John Moses insisted that Bonhoeffer be recognised as 'a reluctant revolutionary', a man who had the courage to shift from Lutheran notions of Christian supercessionism to seeing church and synagogue in a reciprocal relationship, a man who was moved from passivity to strong activism against Nazi tyranny. ${ }^{53}$ Rachel Kohn posed significant hypothetical questions about how the theologian would have or may have reacted to today's jihadist terrorism. ${ }^{54}$ Christine Winter reminded us of the Lutheran context, pointing out that the two noted Lutheran leaders of Bayern and Württemberg, Hans Meiser and Theophil Wurm, in writing their memoirs after the war, could not bring themselves to mention Jews, even in passing. 55 (In 1926, Meiser, who was to become Bishop of Bavaria from 1933 to 1955, wrote that the 'Jewish intellect' was 'excessive and even lascivious' and was 'destroying the moral fundaments of our people'. ${ }^{56}$ In 1938, Wurm accepted the need for the race laws but in 1943 he wrote of his distress at the fate of Jews in mixed marriages and interference 'in the sanctity of marriage' ${ }^{57}$ )

52 'A Cautious Embrace': a Christian-Jewish conference reflecting on the discipleship and legacy of Dietrich Bonhoeffer, St Joseph's Spirituality and Education Centre, Kincumber, NSW, 28-29

November 2008.

${ }^{53}$ Moses, John, 'Dietrich Bonhoeffer's stand on the Jewish Question during the Third Reich', Kincumber, NSW, 28-29 November 2008.

${ }^{54}$ Kohn, Rachel, 'Would Bonhoeffer fight terrorism?', Kincumber, NSW, 28-29 November 2008.

55 Winter, Christine, 'Bonhoeffer and the Jews - a Lutheran context', Kincumber, 28-29 November 2008.

${ }^{56}$ Büttner, 436.

57 Conway, 264-65. 
Debate at the conference was sometimes heated, always considered and ended, politely, with a consensus about caution.

There can be no doubt that Bonhoeffer would have signed the Stuttgarter Schulderklärung and supported the 1950 resolution. Stephen Haynes has provided an insightful analysis of the contradictions and inconsistencies in Bonhoeffer as a 'bystander, resister, victim'. And, he added, as a rescuer. ${ }^{58}$ Bonhoeffer criticised his church for what he considered its purely churchly opposition to the dictatorship; he considered Hitler the 'AntiChrist'; he was forbidden to teach, preach and publish; he was an anti-Nazi counterspy; he helped 14 Jews (11 of them Christian converts) escape to Switzerland. But when he wrote his essay on 'The Church and the Jewish Question', he always used the highly-charged term Judenfrage. Most people reading that in the 1930s would have understood the text: the alien Jew who posed a problem, usually a threat, to Germany. His lifelong conviction was that the 'Jewish Question' would be solved by their conversion. John Moses has written about his 'deep-seated anti-Judaistic theology'.59 But there was no voice from him on the euthanasia issue, or on the Laws of 1935, or on the extermination of Jews. Of the November 1938 pogrom, he did comment that if today the synagogues burn, tomorrow the churches, too, will be set alight'.60 For the Kincumber

58 Haynes, Stephen (2003), ‘Bystander, Resister, Victim: Dietrich Bonhoeffer's Response to Nazism', in Dieter, Donald (ed), Christian Responses to the Holocaust: Moral and ethical issues, New York, Syracuse University Press, 99-118.

${ }^{59}$ Moses, John (2006), 'Dietrich Bonhoeffer's Struggle for ChristianJewish Reconciliation', The Council of Christians and Jews, Victoria, Gesher Journal, item 425.

${ }^{60}$ Raum, Elizabeth (2003), Dietrich Bonhoeffer: Called by God, New 
conference, I read his Letters and Papers from Prison. ${ }^{61}$ While this may well be but a fragment of his writings, and not 'representative', the word 'Jews' appears only twice in 371 pages, and then only en passant. In sum, while Bonhoeffer may have moved quickly along a spectrum that culminated in his anti-Hitler activities, he was, to the end, a product of a longheld and deep-seated Lutheran tradition which saw Jews as a quite separate people, which demonised them and saw their conversion as their only salvation.

In all such discussion, one has to recall the writings of the profound French historian, Jules Isaac. In his influential The Teaching of Contempt, he began the book with a quotation from his friend Pope John XXIII: 'It is a fundamental rule of life never to distort the truth.' The opening chapter has a short headnote: 'All authorities are agreed that a true Christian cannot be an anti-Semite.' 62 However terse, these aphorisms are really not that difficult to understand. There is another from Alexander Donat, a survivor of the Warsaw Ghetto: 'A Christian who witnesses inactively a crime becomes its accomplice.' 63

\section{The Jews and the Jews}

The Centralverein Deutscher Staatsbürger jüdischen Glaubens (The Central Organisation for German Citizens of the Jewish Faith) began life in 1893. This body, known as CV, spent decades fighting attacks, calumnies and libels on Jews. Most often it could only resort to Paragraph 130 of the Criminal Code, on incitement to racial violence, and then, in despair at

York, Continuum International Publishing Group, 109.

${ }^{61}$ Bonhoeffer, Dietrich (1971 edn), Letters and Papers from Prison, (ed) Bethge, Eberhard, London, The Folio Society.

62 Isaac, 20-21.

${ }^{63}$ Donat, Alexander (1968), 'Jewish Resistance' in Out of the Whirlwind: A reader in Holocaust literature, New York, Doubleday \& Company, 53. 
courts ever finding for the Jews, turned to paragraph 166 on crimes against religion. The $\mathrm{CV}$ had much to worry about: the closing of German borders to Jewish immigrants in 1906; the increasingly popular writings of such vigorous antisemites as Eugen Dühring, Heinrich von Treitschke, Arthur de Gobineau and Houston Stewart Chamberlain; the rise of well over 100 institutes for the study of rassenhygiene; the hysteria and Jewhating crudities of Julius Streicher; court biases against Jewish plaintiffs or criminals; the German Youth Movement (Wandervögel) and its many branches that banned Jews; Jews having to form their own university fraternities and Turnerschaften; the constant attacks on Jewish music, Jewish physics, Jewish everything. Yet by March 1933, the CV issued a statement condemning reports of Nazi atrocities against Jews as 'pure invention'. Antisemitism, it said, existed and was of grave concern, 'but it was a domestic affair' ${ }^{64}$

Nearly a year later, in May 1934, Rabbi Leo Baeck met Clarence Pickett, a prominent American Quaker who was visiting Germany to see what could be done for the Jews. Since before Christ, Baeck told him, Jews had been part of Germany and the Worms synagogue had recently celebrated its 900 years of continuous existence. 'The Jews love Germany and they want to stay there'. It was a good time to be a rabbi, he said: his congregation used to number 50 or 60 but now he had to run four services every Saturday. ${ }^{65}$

By September 1935, the newly formed Reichsvertretung der Juden in Deutschland (the National Representation of Jews in Germany) declared that the Nuremberg Laws 'have come as the severest of blows for the Jews in Germany'. But 'they must create a basis on which a tolerable relationship becomes

${ }^{64}$ New York Times, 25 March 1933.

65 Baker, Nicholson (2008), Human Smoke: The beginnings of World War II, the end of civilization, New York, Simon and Shuster, 49-50. 
possible between the German and the Jewish people'. ${ }^{66}$ In effect, they were saying that if that was all they had to live with, they could cope with that.

This is precisely what the Jewish historian and philosopher Gershom Scholem always railed against: this one-sided, unrequited love affair between Germans and Jews. In his well known essay on the myth of German-Jewish dialogue, Scholem excoriated these particular Jews for their delusions and their self-deception. They may have had a passionate love for their Vaterland but the Vaterland had never had such feelings for them. It took two to make a dialogue and the Jews, he said, 'spoke only to themselves'. For 200 years, Scholem wrote, Jews could have heard the clumping of antisemitic boots behind them;67 Helmreich described that phenomenon as the 'cannonball of anti-Semitism [that] had started rolling down the hill many years in the past'. ${ }^{68}$ They didn't want to see or hear.

In 1932, an esteemed American writer, Edgar Mowrer, visited Germany. After dinner with a Jewish banker who had donated money to the Nazi Party, Mowrer wondered aloud 'how the People of Israel have managed to survive so many thousands of years when they obviously have a strong suicidal urge'. The banker scoffed at Hitler's rhetoric: 'just talk', he said. ${ }^{69}$

Am I blaming Jews for their demise? Assuredly not. But it must have been clear to many, as it was to people like Scholem and political scientist Guenter Lewy, that German Jews had surrendered part of their souls, part of their

66 Documents on the Holocaust (1981), Jerusalem, Yad Vashem, 84.

${ }^{67}$ From Cynthia Ozick's essay on Scholem, 'The Heretic', New Yorker Magazine, 2 September 2002.

${ }^{68}$ Helmreich, 364.

${ }^{69}$ Baker, 33. 
historical experience about tenure and tolerance in foreign lands, in order to devote themselves to Germanness; and in order to do that, they even dedicated themselves to disassociating themselves totally from the allegedly coarse, loud, uncouth, Yiddish-speaking Ostjuden, the East Europeans Jews from neighbouring Poland. ${ }^{70}$ But they failed to see that they had never been, nor ever would be, part of 'us Germans'. This may seem a harsh conclusion, but Scholem was hardly alone in expressing it. Ursula Büttner contends that 'for the majority of German Protestants, Jews were and always would be strangers no matter how assimilated they were'; this aversion, she concludes, extended to 'Jewish Christians', people who not only once adhered to a foreign religion but who still 'belonged to a foreign people' ${ }^{71}$

Some colleagues who have heard me talk on this topic ask whether I am treading the path of Daniel Goldhagen, ${ }^{72}$ asserting that Germany was and is somehow 'genetically' incapable of embracing cultural diversity and was always a repository or reservoir of an 'eliminationist antisemitism'. No, is the answer, but I do subscribe to the view that German Jews had an unrequited love affair with Germanness. In the late eighteenth century the philosopher Moses Mendelssohn, the father of the Jewish Enlightenment, always wanted to play chess with Gotthold Lessing, the doyen of German kultur. Observers of friendships such as this one would comment: what kind of a faith is it that will surrender itself in order to belong where patently they can never belong?

${ }^{70}$ Aschheim, Steven (1982), Brothers and Strangers: The East European Jew and the German Jewish consciousness, 1800-1923, Madison, University of Wisconsin Press.

${ }^{71}$ Büttner, 457-58.

${ }^{72}$ Goldhagen, Daniel (1996), Hitler's Willing Executioners: Ordinary Germans and the Holocaust, New York, Alfred E Knopf. 


\section{Seeking Explanations}

Motives and causal connections in history are always retrospective and, inevitably, they are often reflective, if not speculative. But they do need serious consideration.

First, while it is clear that there were fractures, fractions and frictions within all Christian churches - on doctrine, on Gleichshaltung or the 'synchronisation' ordered by Hitler, on euthanasia - was their general attitude to the Nazi state one of support or mere acquiescence? The question can be asked another way: was church silence, indifference or hostile indifference towards Jews a norm to which most people conformed? Christopher Browning, among a number of Holocaust scholars, has looked hard for the 'transmission belts' that drove the Nazis and their 'sacred mission'. Fear, coercion, obedience and dehumanisation have been analysed in many texts (including this volume). Browning has found an answer, perhaps the answer, in his research on the 500 men in Reserve Police Battalion 101 from Hamburg and later transferred to the Lublin district of Poland. ${ }^{73}$ When their commandant, Major Wilhelm Trapp, offered them the chance of not participating in the rounding up and shooting of women and children from the town of Jozefow in July 1942, fewer than 15 stepped forward and opted for 'other duties'. These reservists were not Nazis and not specially trained; these family-men, the Ordinary Men of the book title, were unfit for military service, even for the real police. After initial despair, trauma and breakdown after the first day's 'work', this group became the most proficient killers of Jews in Poland. What kept some 485 united initially, Browning concluded, was male conformity.

Second, the answer may lie in tradition which, in a sense,

${ }^{73}$ Browning, Christopher (1992), Ordinary Men: Reserve Police Battalion 101 and the Final Solution in Poland, New York, HarperCollins. 
is really a chronicle of conformity to lore, customs, norms, values and beliefs. Churchmen of all denominations have grown up with an ingrained and indelible feature of Western intellectual history, namely, antisemitism, one facet of which is that the Jews are now Israel carnalis (in the flesh) and no longer Israel verus (the true religion). Sixteen centuries of this is, indeed, weighty tradition - and heavy conformity.

Third, there is a realisation that in many circumstances the forces of nationalism and ethnic fire transcend religious adherence and religious duties of care. Many, if not most, German Catholics were clearly Germans first and foremost. Certainly the 'brown priests' of Germany were suffused by fatherland fervour. Father Dr Phillipp Haeuser was not alone in his pursuit of Nazi ideals and, as we have seen, the more elevated and reputable bishops saw the promises and premises of National Socialism as the greater attraction. Some of the 'brown priests', Spicer wrote, had less noble motives, such as disaffection with clergydom, conflict with their superiors, and plain, naked ambition.

Fourth, could an explanation lie in the fact that these churchmen simply didn't know any better, or any more than they cared to know? There is a crucial question here and in all discussions about the role of Christianity in times of gross human violence: what knowledge would it have taken to deflect them from their paths of support or acquiescence? Had they had the chance to look into a viewing instrument that showed them scenes from the Implementation of the Law for the Restoration of the Professional Public Service in 1933, from the Nuremberg Laws on Reich Citizenship in 1935, from 'Kristallnacht' in 1938, the first mobile gas vans in operation at Chelmno in December 1941, or of the Einsatzgruppen at their 'work' in 1941 and 1942, would those images have deflected them? Now we look at the body bags and human wreckage of Vietnam, Iraq and Afghanistan and ask ourselves how we could possibly have gotten there. Could they not have seen 
'Kristallnacht' as the curtain-raiser, especially after Göring had said that he would not like to have been a Jew in Germany at that time? We, the populaces, were lied to, and continue to be lied to, about many things, but the real question is what the liars knew. Did they know enough to suggest that they shouldn't go there? In a strange truth, Göring didn't lie: in 1936 he said that Germany would deal with the 'Jewish Question' so oder so, one way or another. These clergymen may not have known about the death camps until later in 1943, but they knew enough-enough for us to sit at the thousands of conferences, seminars and university courses since those events and be incredulous that men could make the choices and decisions that they did make in the face of what they knew.

A fifth explanation comes to mind: enough indifference, lack of feeling or passion, to demur, desist or oppose. Herein, perhaps, lies the vexed matter of worthiness, or the absence thereof. Jews, after all, not only killed Christ but they rejected his messianic descent and purpose, they desecrated the host, they allegedly killed Christian children to make matzot at Passover time, they were the peasant peoples' worst nightmare, the pawnbrokers and the tax collectors, they caused and spread the Black Plague, they were the urbandwellers who seemingly turned their backs on völkisch blood and soil and forests, who modernised the world and who tried to make rational the celebrated cults of irrationalism, who foreswore the sacred pig so precious in German romanticism, und so weiter. Who, indeed, could feel for such people? The hostile part of it is so much clearer cut.

Finally, the matter of want and not want. In political science, social science generally, in history and philosophy, we always look for explanations in ideology, in administrative and organisational behaviour, in social physics, in procedure and mechanics, in psychological states of mind, in individual or group behaviour and, all too often, in what we call 'grand theory'. There are times when the explanations are so simple that we can't bring ourselves to 
believe that something so plain, so unadorned, can answer the big questions.

Much has been written about the charade that was the Evian Conference in 1938, the meeting called to deal with the crisis of German Jewry. Of the nations present, 31 offered some or other technical explanation for not taking any emigrants. ${ }^{74}$ Australia's delegate, Lieutenant-Colonel $\mathrm{T}$ W White, said 'it will no doubt be appreciated also that as we have no real racial problems, we are not desirous of importing one... ${ }^{\prime 75}$ Only one nation, the little Dominican Republic, said it wanted 100,000 Jews. Wanted is perhaps misleading: what General Rafael Trujillo wanted was salvation for his sullied reputation, but in the end he took 500 . Not enough has been written about the attitudes of Churchill and Roosevelt towards Jews in crisis, about their not wanting to take in a clearly imperilled people. Reams have been written about the bombing of the railway lines to Auschwitz, about the British who said they couldn't do it technically so it had to be the Americans and the Americans who couldn't do it because of this, that and the other. Martin Gilbert has analysed the many rationalisations in his Auschwitz and the Allies and his documentary film of that title. In the end, the answer is simple: those at the helms of the Allies didn't want to. More reams have been written about Pius XII and his inaction, or at least his overt inaction. Paul O'Shea has traversed all the arguments in his recent book on Eugenio Pacelli. Why was this shy and cloistered man, this complex and convoluted

${ }^{74}$ All delegates expressed sympathy for German Jewry. Golda Meir was an observer from Palestine. She said later that if all that Evian could produce was sympathy of this kind, she never wanted to hear that word for, or about, Jews ever again.

75 Bartrop, Paul, (ed) (1995), False Havens: The British Empire and the Holocaust, Lanham, Maryland, University Press of America, 64-65. 
man, in so many ways a good man, so voluble on the Church and so silent on the Jews? Why, when he had the chance and even when the Nazis were in some fear of what he would say in his Christmas 1942 broadcast, did he agree to mention atrocities in general but no atrocity against Jews and against Poles? The answers are complex at one level, to do with Pius' saturation in the Catholic tradition of supercessionism, of the Jews as always 'the lesser victims', where, in historian Saul Friedländer's language, 'whatever the motivations of the passivity...it always resulted from a choice in which the Jew was always less than whatever other consideration he was weighed against' ${ }^{\prime}{ }^{76}$ At another level, the key level, the answer was simple-because he didn't want to. He wanted to confront the satanic Communist menace and he did so with vigour; he didn't want to confront the National Socialists, even though he saw them as thugs and so, quite simply, he didn't.

We need to pause for a good while to consider Friedländer's diagnosis: apart from some 24,000 Righteous Among the Nations, and less than a handful of righteous nations, the Jews were always less than anything else they were weighed against, always less worthy. For a people always considered more than, more manipulative, more controlling, more intellectual, more lascivious, more baleful, more destructive, their modern history has been that of a minorité fatale, always less than.

In conclusion, we need to spend more time-as scholars, as students, as people with religious beliefs or at least, with an interest in the role of religion-examining and debating omission rather than commission, not wanting, not doing. Jews particularly seek to detect and to combat overt antisemitism. They waste endless hours, efforts and nervous

${ }^{76}$ Freidländer, Saul (1976), 'Some aspects of the historical significance of the Holocaust', the Jerusalem Quarterly, 1, Fall, 36-59. 
energy running down offbeat talkback radio comments, ambiguous or unflattering crossword puzzle clues, perceived or real enough pro-Arab biases in the media. Anti-Defamation League commissions conduct surveys on overt antisemitism across the continents, on Palestine Authority school syllabus materials, and write texts on ways to counteract the Iranian threats to Israel and to Jews generally. They, and other such anti-racism bodies, spend almost no time on 'omissionary' antisemitism, the kind that makes Jews 'lesser victims' or unworthy victims - or the kind that doesn't consider them at all. 